\title{
ARE CENTRAL BANK RESERVES AN IMPORTANT INSTRUMENT FOR STABILITY IN EXCHANGE RATES?
}

\author{
DOI: 10.17261/Pressacademia.2018.998 \\ JBEF- V.7-ISS.4-2018(7)-p.376-381
}

\section{Yunus Acci}

Iskenderun Technical University, Faculty of Business and Management Sciences, Department of Economics, Hatay, Turkey. yunus.acci@iste.edu.tr, ORCID: 0000-0002-3385-9087

To cite this document

Acci, Y. (2018). Are central bank reserves an important instrument for stability in exchange rates?. Journal of Business, Economics and Finance (JBEF), V.7(4), p.376-381.

Permemant link to this document: http://doi.org/10.17261/Pressacademia.2018.998

Copyright: Published by PressAcademia and limited licenced re-use rights only.

\section{ABSTRACT}

Purpose- In developing countries, the most important macroeconomic variable shaping individuals' expectations for economic stability is the nominal exchange rate. For this reason, the first impact of central banks monetary policy implementation results comes out at nominal exchange rate. In this study, the relationship between the nominal exchange rate and the gross foreign exchange reserves of the central bank has been investigated.

Methodology- In this study, Dickey-Fuller (1981, ADF) and Phillips-Perron (1988, PP) unit root tests, asymmetrical causality test and lastly Bootstrap Rolling Window Causality tests developed by Balcılar et al. (2010) have been used.

Findings- There is a causal relationship between the nominal exchange rate and central bank reserves. Central bank interfere in nominal exchange rate with its reserves rather than interest policy.

Conclusion- As a result of the empirical analysis, causality has been found from positive shocks coming to nominal exchange rates to positive shocks in central bank gross foreign exchange reserves and from positive shocks formed in central bank gross foreign exchange reserves to negative shocks coming in nominal exchange rate.

Keywords: Exchange rates, central banking, causality, asymmetric causality, bootstrap rolling window causalityç JEL Codes: E58, F31, F41

\section{INTRODUCTION}

In the economic literature, the most important variable in macroeconomic indicators is the exchange rate. The exchange rate variable appears in many economic policies such as the monetary condition index, the Taylor rule, transmission mechanisms the exchange rate transition effect. For this reason, it is important for policymakers to put forward the determinants of exchange rate. The fluctuations in nominal exchange rates shape the expectations of households towards economic course. According to Calvo and Reinhart (2002), central banks save substantial amount of reserve in order to prevent the fluctuaitons in nominal exchange rate. However, these reserves that central banks save effect resource allocation in financial markets. In this study, it was investigated whether the central banks are effective in influencing the nominal exchange rate. With the causality between shocks used in study and causality tests based on Rolling Window Regression, it is aimed to complete an important deficiency in the empirical literature.

In the Turkey economy, important economical events have occured in the last 30 years. With the 1994, 1999, 2000 and 2001 crises, important fluctuations have occured in nominal exchange rate and the economic expectations of household were spoiled substantially. During this period, the central bank applied adjustable fixed exchange rate, controllable floating exchange rate and finally floating exchange rate policies respectively. Since 2003 , central bank has carried out floating exchange rate regime and inflation-targeting regime together. With the inflation-targeting regime, the central bank's basic target has been price stability. With the aim of limiting the exchange rate transition effect, it has struggled to stabilize the nominal exchange rate. For this purpose, it has used alternative monetary policy means and the reserves has been one of them. 
Graphic 1: Development of Nominal Foreign Exchange Rate by Years

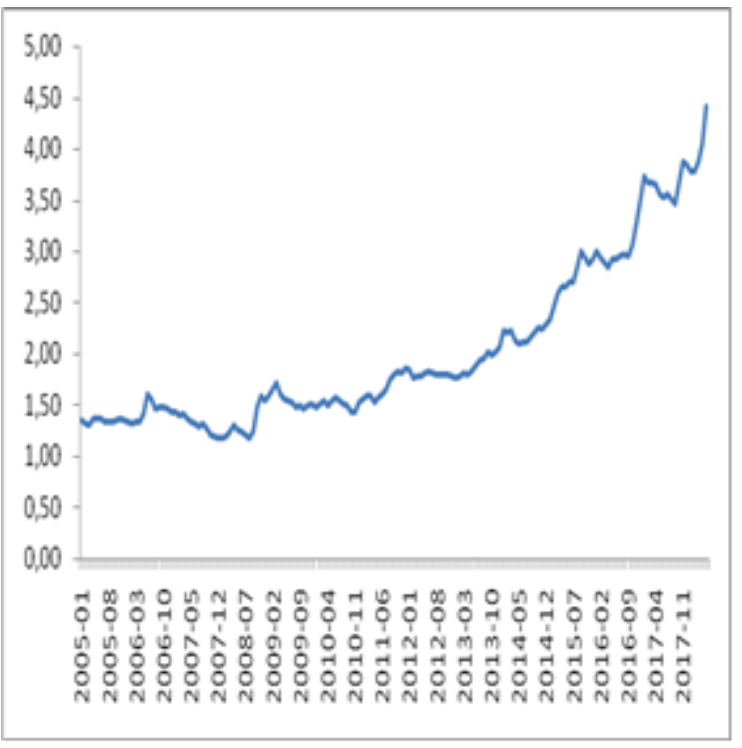

Graphic 2: Development of Central Bank Gross Foreign Exchange Reserves by Years

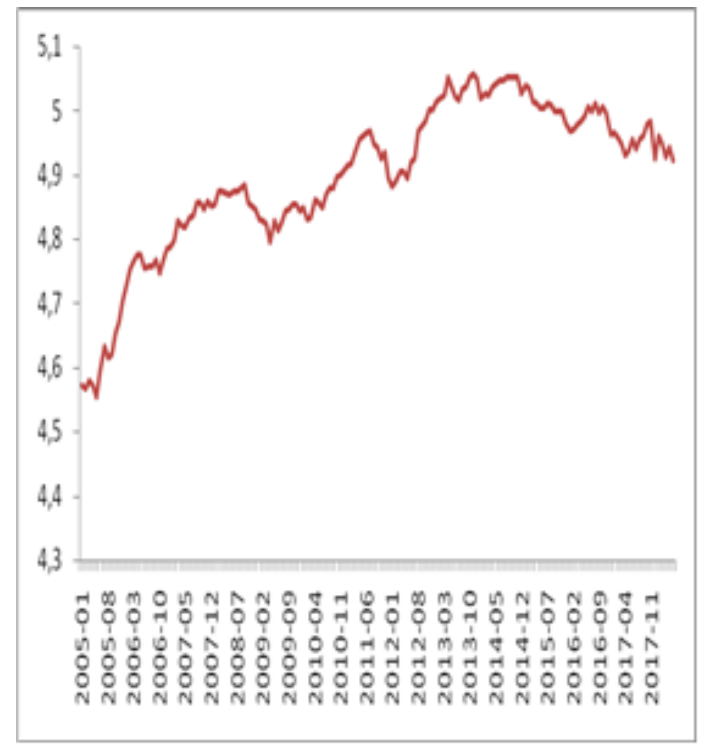

Looking at nominal exchange rates over the years, a significant upward trend is seen. Central bank reserves have maintained the upward trend but they have experienced fluctuations. It decreased between 2008-2009 and 2011-2012. When the rise in nominal exchange rate on the same dates is considered, it is seen that at least visually central bank reserves have not been used. In the empirical literature, there are many studies investigating the exchange rate and reserve relation in Turkey's economy. Balaylar and Ural (2007), Kibritçioğlu (2001), Alper and Ardıç (2006), Balaylar (2011) and Parlaktuna (2005) suggested that central bank reserves should be used for sterilisation in the exchange market. While Bayat et al. (2014) found that central bank reserves does not affect the exchange rate, Kasman and Ayhan (2008) found causality from the nominal exchange rate to the central bank reserves.

\section{DATA AND METHODOLOGY}

In this study, the nominal exchange rate that belongs to the period between January 2005 and May 2018 in Turkey the relationship between (NEER) and the central bank gross exchange reserves (RES) has been investigated. Datas have been obtained from Central Bank of the Turkish Republic Electronic Data Distribution System. While the relationship between variables has been investigated, current developments in time-series analysis have been utilized. In this context, linear unit root tests that not considering the structural breaks developed by Dickey-Fuller (1981, ADF) and Phillips-Perron (1988, PP), asymmetrical causality test and lastly Bootstrap Rolling Window Causality tests developed by Balcılar et al. (2010) have been used.

The equations based on the ADF unit root test can be written as follows (Sevüktekin ve Nargeleçekenler, 2007:321).

$$
\begin{aligned}
& \Delta Y_{t}=\delta Y_{t-1}+\sum_{r=1}^{f} \delta r \Delta Y_{t-r}+\varepsilon_{t} \\
& \Delta Y_{t}=\mu+\delta Y_{t-1}+\sum_{r=1}^{f} \delta r \Delta Y_{t-r}+\varepsilon_{t} \\
& \Delta Y_{t}=\mu+\beta_{t}+\delta Y_{t-1}+\sum_{r=1}^{f} \delta r \Delta Y_{t-r}+\varepsilon_{t}
\end{aligned}
$$


The ADF unit root test assumes that the shocks have an independent and constant variance (Sevüktekin ve Nargeleçekenler, 2007:363). Phillips-Perron developed an alternative unit root test to resolve this deficiency. Phillips-Perron is based on the following test (Phillips ve Perron, 1988:341)

$$
\begin{aligned}
& Z_{\bar{\varphi}}=T(\bar{\varphi}-1)-\frac{1}{2}\left(\bar{\sigma}_{T \ell}^{2}-\bar{\sigma}^{2}\right)\left[T^{-2} \sum_{2}^{T} y_{t-1}^{2}\right]^{-1} \\
& Z\left(t_{\bar{\varphi}}\right)=\left(\bar{\sigma} / \bar{\sigma}_{\varepsilon}\right) t_{\bar{\varphi}}-\frac{1}{2}\left(\bar{\sigma}_{T \ell}^{2}-\bar{\sigma}^{2}\right)\left[\left(T^{-2} \sum_{t=1}^{T} \varepsilon_{t-1}^{2}\right)^{1 / 2}\right]^{-1}
\end{aligned}
$$

In the Hatemi J-Roca causality test, the causality of positive and negative shocks is investigated. The following model is used in Hatemi J-Roca granger causality test (Acci, 2015:73).

$$
\begin{aligned}
& y_{1 t}=y_{1 t-1}+\varepsilon_{1 t}=y_{10}+\sum_{i=1}^{t} \varepsilon_{1 i}^{+}+\sum_{i=1}^{t} \varepsilon_{1 i}^{-} \\
& y_{2 t}=y_{2 t-1}+\varepsilon_{2 t}=y_{20}+\sum_{i=1}^{t} \varepsilon_{2 i}^{+}+\sum_{i=1}^{t} \varepsilon_{2 i}^{-}
\end{aligned}
$$

Using bootstrap rolling window approach, it was analyse the time-varying causal links between nominal exchange rate and central bank reserve. Balcılar et al. (2010) bootstrap rolling window causality test uses residual-based bootstrap technique based corrected-LR tests in order to investigate the causal nexus between nominal exchange rate and central bank reserve (Balcilar et al, 2010:1400).

In the Balcilar et al(2010) bootstrap Rolling window causality test, it was used bootstrap version of Toda and Yamamoto (1995) causality tests due to several advantages it possesses(Balcılar et al, 2010:1400).

\section{EMPRICAL RESULTS}

When the coefficient of correlation is examined, it is seen that there is a positive relation between two variable. While the model is being formed, in order to see the dynamic relations between variables, vector auto regression (VAR) model will be installed. As discussed in the VAR model methodology, it is necessary to find the levels that variables are stable. For this purpose, linear unit root tests that not considering the structural breaks developed by Dickey-Fuller (1981, ADF) and Phillips-Perron (1988, PP) will be carried out in econometric literature.

Table 1: Correlations between Variables

\begin{tabular}{lll}
\hline & NEER & RES \\
\hline NEER & 1 & - \\
RES & 0.533 & 1 \\
\hline
\end{tabular}

Table 2: ADF (1981) and PP (1988) Unit Root Test Result

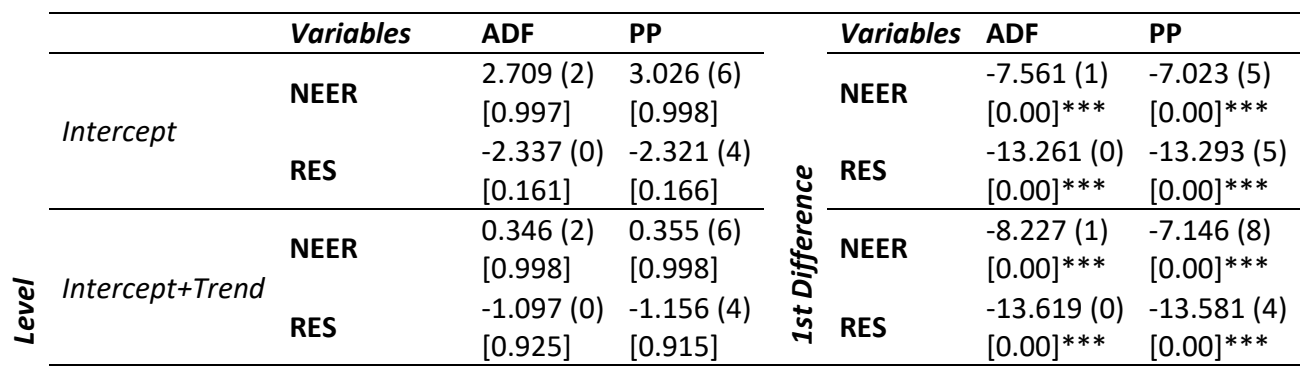


Note: ${ }^{* * *}{ }^{* *}$ and ${ }^{*}$ values show the stationarity of the series in $\% 1 . \% 5$ and $\% 10$ significance levels respectively. According to Schawarz information criteria, the values in bracket show optimal lag length. The values in square bracket show probability values. For ADF test: Mac Kinnon (1996) critical values $1 \%$ fixed. For $5 \%$ and $10 \%$ values 3.485. -2.885.-2.579 respectively and for fixed + trend $1 \%$. For $5 \%$ and $10 \%$ probability values -3.483. -2.884 - -2.579 respectively. For PP test: Mac Kinnon (1996) critical values $1 \%$ fixed. For $5 \%$ and $10 \%$ values 3.485. -2.885. -2.579 respectively and for fixed + trend $1 \%$. For $5 \%$ and $10 \%$ probability values -4.033 . -3.446 and -3.148 respectively.

It is seen that both nominal exchange rate and central bank gross exchange reserves have unit root in level values. However, when the first difference of the variables is taken, it appears to be stationary. For Hatemi J and Roca (2014) causality test and Balcılar et al. (2010) bootstrap rolling window, obtained from the vector auto regression model, optimal lag length has been set to 3 . In order to see the asymmetrical relations between variables, causality test developed by Hatemi and Roca (2014) has been implemented.

Table 3: Hatemi J-Roca (2014) Asymmetric Causality Test Results

\begin{tabular}{lllll}
\hline Direction of Causality & MWALD & $\begin{array}{l}\text { \%1 } \\
\text { Bootsrap CV }\end{array}$ & $\begin{array}{l}\text { \%5 } \\
\text { Bootsrap CV }\end{array}$ & $\begin{array}{l}\text { \%10 } \\
\text { Bootsrap CV }\end{array}$ \\
\hline${\text { (NEER })^{+} \neq>(\mathrm{RES})^{+}}$ & $4.739(0.094)^{*}$ & 9.609 & 6.279 & 4.807 \\
$(\mathrm{NEER})^{+} \neq>(\mathrm{RES})^{-}$ & $0.316(0.574)$ & 7.045 & 4.060 & 3.045 \\
$(\mathrm{NEER})^{-\neq>}(\mathrm{RES})^{-}$ & $0.370(0.543)$ & 6.711 & 3.652 & 2.685 \\
$(\mathrm{NEER})^{-} \neq>(\mathrm{RES})^{+}$ & $1.053(0.305)$ & 7.078 & 4.103 & 2.974 \\
\hline$(\mathrm{RES})^{+} \neq>(\mathrm{NEER})^{+}$ & $0.240(0.887)$ & 9.481 & 6.537 & 4.596 \\
$(\mathrm{RES})^{+} \neq>(\mathrm{NEER})^{-}$ & $7.424(0.00)^{* * *}$ & $7.253^{* * *}$ & $3.816^{* *}$ & $2.590^{*}$ \\
$(\mathrm{RES})^{-} \neq>(\mathrm{NEER})^{-}$ & $1.268(0.260)$ & 8.194 & 4.191 & 2.866 \\
$(\mathrm{RES})^{-} \neq>(\mathrm{NEER})^{+}$ & $3.421(0.064)^{*}$ & 6.936 & 4.020 & $2.770^{*}$ \\
\hline
\end{tabular}

Note: $\neq>$ The notation shows null hypothesis that does not have causality. The values in bracket indicate probability values asymptotically. ***. ** and * values show causality relation between variables at significance levels of $1 \% 5 \%$ and $10 \%$ respectively. The Bootstrap number is 10.000 .

Hatemi J-Roca (2014) asymmetrical causality test's null hypothesis states that there is no causality from nominal exchange rate to central bank reserves. The alternative hypothesis remarks that there is causality from nominal exchange rate to central bank reserves. Two different test statistics are applied in the decision phase. Initially, the values in bracket indicate the probability values distributed asymptotically. If the probability values in bracket are below the \%1 (0.01), \%5 (0.05) and $\% 10$ (0.1) significance levels, the alternative hypothesis that there is causality from nominal exchange rate to central bank reserves is accepted. On the other hand, If MWALD test statistics are over the bootstrap critical values that are calculated for significance levels, the alternative hypothesis is accepted again. Accordingly, the positive shocks that come to nominal exchange rate (rising of nominal exchange rate) cause positive shocks in central bank exchange rate (rising of reserves) at $10 \%$ significance level asymptotically. The positive shocks in central bank gross exchange rate (rising of reserves) cause negative shocks that come at nominal exchange rate. On the contrary, negative shocks at central bank gross exchange rate (decrease of reserves) cause positive shocks that comes at nominal exchange rate at $10 \%$ significance level asymptotically. According to Bayat et al (2015) the central bank considers nominal exchange rate's mobility rather than it's value. Because, in developing countries, nominal exchange rate shapes economic actors' expectations for economic stability. At times when the mobility in nominal exchange rate rises, individuals worry about economic course. According to Koçyiğit et al (2013), central banks want to control the deviations at equilibrium price of exchange rate in order to control inflation. Therefore, they presume that exchange rate will act as a nominal anchor in controlling inflation. With a sterilized exchange rate intervention, its effect on inflation will be minimized with the exchange rate transition effect. 
Graphic 3: Bootstrap Rolling Window Causality Test Results (Balcılar et al. (2010)

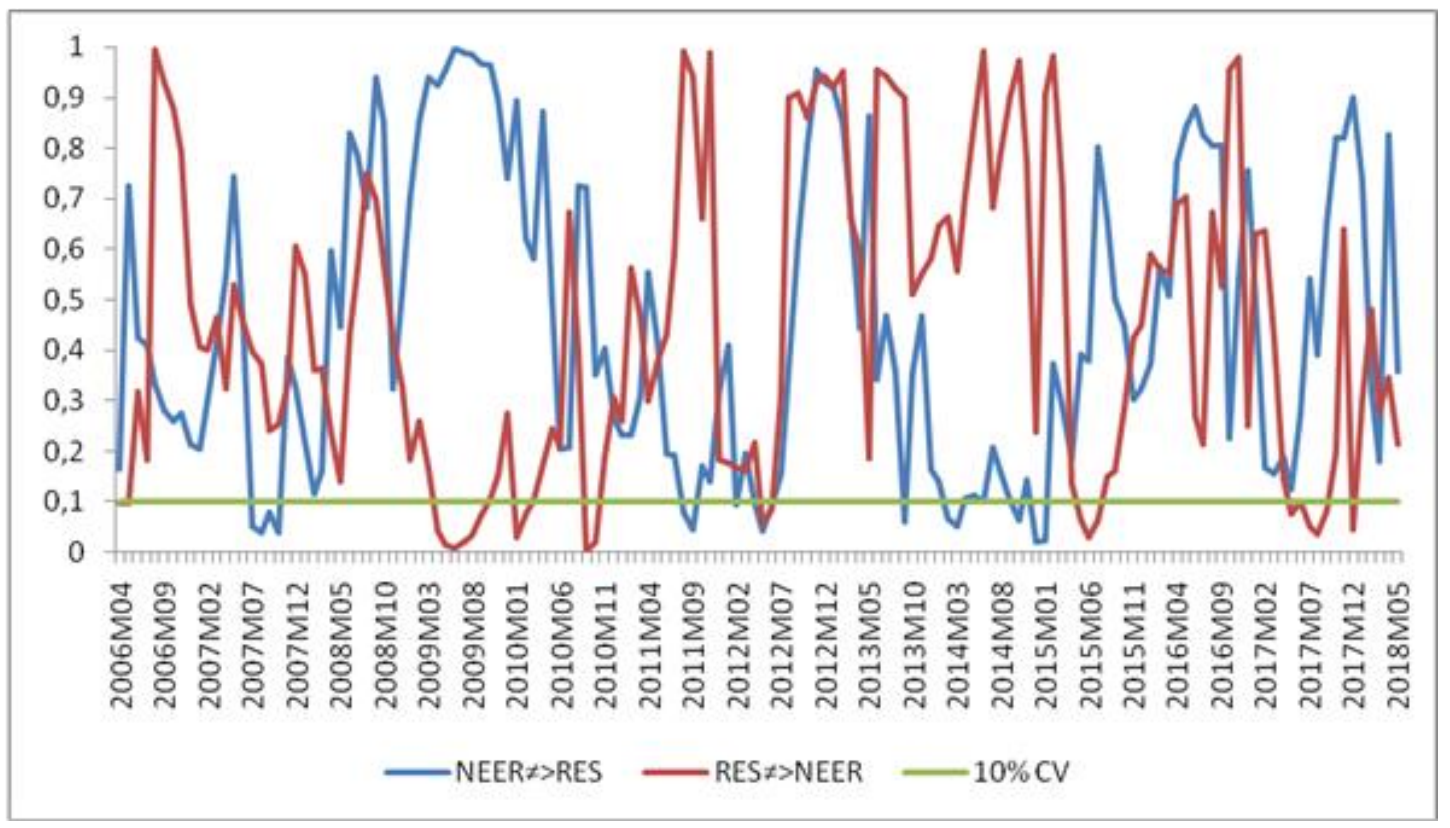

The hypothesis in Balcilar et al(2010) bootstrap Rolling window causality test are the same as Hatemi J-Roca (2014) asymmetric causality test too. The test's null hypothesis indicates that there is no causality from nominal exchange rate to central bank reserves. The alternative hypothesis remarks that there is causality from nominal exchange rate to central bank reserves. In the decision period, probability values are used again. If probability values are below \%1 (0.01), \%5 (0.05) and $\% 10(0.1)$, the alternative hypothesis, which argues that there is causality from nominal exchange rate to central bank reserves in that month, is accepted. According to this, from exchange rate to central bank gross exchange reserves, there is causality on the dates of on July, August, September and October 2007, August and September 2011, February, April, May and June 2012, September 2013, February, March, June, October, December 2014 and January 2015. From central bank gross exchange reserves to nominal exchange rate, there is causality in the months of April and May 2006, April, May, June, July, August and September 2009, January, February, September and October 2010, May and June 2012, May, June and July 2015, July and December 2017. Kar et al. (2016) the first asymmetric effects in exchange rate arise in the money supply. This effect affects the central bank's purpose of stabilization of currency firstly. On these dates, low interests that emerge due to central bank's increases in money supply lead to the exit of foreign capital. The reserve declines that show up in Graphic 2 show that central bank interfere in nominal exchange rate with its reserves rather than interest policy.

\section{CONCLUSION}

In this study, the relation between nominal exchange rate and central bank reserves in Turkey's economy between January 2005-May 2018 has been studied. Current developments in the time series method have been utilized in the study. In the empirical analysis, firstly a positive and in the middle relationship between the variables has been found. In the sequential unit root test not considering the structural breaks developed by Dickey-Fuller (1981, ADF) and Phillips-Perron (1988, PP), it has been concluded that it has unit root in level values parallel to the economic crisis experienced in Turkey's economy and when the first difference is taken, it has been concluded that the variables are stable (purified from economic shocks). In the Hatemi J and Roca (2014) asymmetrical test, it has been determined causality relation from positive shocks that come to nominal exchange rate towards positive shocks in central bank gross exchange reserves and from positive shocks in central bank gross exchange reserves towards negative shocks coming in nominal exchange rate. Additionally, it has been found causality from negative shocks in central bank gross exchange reserves towards positive shocks coming in nominal exchange rate. In the Balcilar et al. (2010) bootstrap rolling window causality test, it is seen that there is causality relation on different dates for 17 months, from nominal exchange rate to central bank gross exchange reserves, for 19 months from central bank gross exchange reserves to nominal exchange rate. When the results are considered as a whole, the source of causality that comes out for 17 months from nominal exchange rate that emerges in Balcilar et al. (2010) bootstrap rolling window causality test towards central bank gross exchange reserves, is the interaction of positive shocks that come to nominal exchange rate and positive shocks in central bank gross exchange reserves. The source of causality that comes out 
for 19 months from central bank gross exchange reserves to nominal exchange rate is the interaction of positive shocks in central bank gross exchange reserves and negative shocks in nominal gross exchange rate.

\section{REFERENCES}

Açcı, Y. (2015). Türkiye'de döviz kuru geçişkenliğinin ihracat ve ithalat fiyatları üzerindeki etkisi. İnönü Üniversitesi Sosyal Bilimler Enstitüsü Doktora Tezi, Malatya.

Alper, E., Ardıç, P. (2006). Serbest kur rejimi döneminde döviz kuru öngörüsü: Türkiye’ye uygulama. Uluslararası Ekonomi ve Dış Ticaret Politikaları, 1(1), pp. 51-68.

Balaylar N., Ural, M. (2007). Bankacılık sektöründe yüksek risk ve baski endeksleri. Finans, Politik ve Ekonomik Yorumlar, 44(509), pp. 47-57.

Balaylar, N. (2011). Türkiye'de döviz piyasasi müdahalelerinin sterilizasyon maliyeti. DokuzEylül Üniversitesi Sosyal Bilimler Enstitüsü Dergisi, 13(3), pp. 19-38.

Balcilar, M., Ozdemir, Z. A., Arslanturk, Y. (2010). Economic growth and energy consumption causal nexus viewed through a bootstrap rolling window. Energy Economics. 32(6), 1398-1410.

Bayat, T., Senturk, M., Kayhan, S. (2014). Exchange rates and foreign exchange reserves in Turkey: nonlinear and frequency domain causality approach. Theoretical \& Applied Economics, 21(11).

Bayat, T. Özcan ,B., Taş, Ş. (2015). Türkiye'de döviz kuru geçiş etkisinin asimetrik nedensellik testleri ile analizi. Eskişehir Osmangazi Üniversitesi IiBF Dergisi,10(2), 7-30.

Calvo, G., Reinhart, C. (2001). The twin crises: the causes of balance-of payments problems. George Washington University Department of Economics Working Paper, 89(3), pp. 473-500.

Dickey, D., Fuller, W. (1979). Distribution of the estimators for autoregressive time series with a unit root. Journal Of The American Statistical Association, 74, Ss:427- 431.

Dickey, D., Fuller, W. (1981). Likelihood ratio statistics for autoregressive time series with a unit root. Econometrica, 49, Ss:1057-72.

Hatemi-J, A., Roca, E. (2014). BRICs and PIGS in the presence of Uncle Sam and big brothers: who drive who? Evidence based on asymmetric causality tests. Griffith University, Department of Accounting, Finance and Economics.

Kar, M., Bayat, T., Kayhan, S. (2016). Impacts of credit default swaps on volatility of the exchange rate in Turkey. International Journal of Economics and Finance, 4(14).

Kasman, A., Ayhan, D. (2008). Foreign exchange reserves and exchange rates in Turkey: structural breaks, unit root and cointegration. Economic Modeling, 25, pp. 83-92.

Koçyiğit, A., Kayhan, K., Bayat, T. (2013). Enflasyon hedeflemesi rejiminde öğrenme süreci ve asimetri: Markov Switching yaklaşımı. Eskişehir Osmangazi Üniversitesi iïB Dergisi,8(1), 191-212.

MacKinnon, J. (1996). Numerical distribution functions for unit root and cointegration tests. Journal of Applied Econometrics, 11, ss:601618.

Parlaktuna, I. (2005). Exchange market pressure in Turkey 1993-2004: an application of theGirton-Roper monetary model. International Economic Journal, 19 (1), pp. 51-62.

Phillips, P., Perron, P. (1988). Testing for a unit root in time series regressions. Biometrica, 75, 335-346.

Sevüktekin, M., Nargeleçekenler M. (2010). Ekonometrik zaman serileri analizi. 3. Baskı, Ankara: Nobel Yayınevi. 